\title{
GEOSTATISTICAL INVESTIGATIONS OF DISPLACEMENTS ON THE BASIS OF DATA FROM THE GEODETIC MONITORING OF A HYDROTECHNICAL OBJECT
}

\author{
BARBARA NAMYSŁOWSKA-WILCZYŃSKA, JANUSZ WYNALEK \\ Wrocław University of Science and Technology, Faculty of Civil Engineering, \\ Wybrzeże Wyspiańskiego 27, 50-370 Wrocław, Poland \\ e-mail: barbara.namyslowska-wilczynska@pwr.edu.pl,janusz.wynalek@pwr.edu.pl
}

\begin{abstract}
Geostatistical methods make the analysis of measurement data possible. This article presents the problems directed towards the use of geostatistics in spatial analysis of displacements based on geodetic monitoring. Using methods of applied (spatial) statistics, the research deals with interesting and current issues connected to space-time analysis, modeling displacements and deformations, as applied to any large-area objects on which geodetic monitoring is conducted (e.g., water dams, urban areas in the vicinity of deep excavations, areas at a macro-regional scale subject to anthropogenic influences caused by mining, etc.). These problems are very crucial, especially for safety assessment of important hydrotechnical constructions, as well as for modeling and estimating mining damage.

Based on the geodetic monitoring data, a substantial basic empirical material was created, comprising many years of research results concerning displacements of controlled points situated on the crown and foreland of an exemplary earth dam, and used to assess the behaviour and safety of the object during its whole operating period. A research method at a macro-regional scale was applied to investigate some phenomena connected with the operation of the analysed big hydrotechnical construction.

Applying a semivariogram function enabled the spatial variability analysis of displacements. Isotropic empirical semivariograms were calculated and then, theoretical parameters of analytical functions were determined, which approximated the courses of the mentioned empirical variability measure. Using ordinary (block) kriging at the grid nodes of an elementary spatial grid covering the analysed object, the values of the $Z^{*}$ estimated means of displacements were calculated together with the accompanying assessment of uncertainty estimation - a standard deviation of estimation $\sigma_{k}$. Raster maps of the distribution of estimated averages $Z^{*}$ and raster maps of deviations of estimation $\sigma_{k}$ (in perspective) were obtained for selected years (1995 and 2007), taking the ground height 136 $\mathrm{m}$ a.s.l. into calculation. To calculate raster maps of $Z^{*}$ interpolated values, methods of quick interpolation were also used, such as the technique of the inverse distance squares, a linear model of kriging, a spline kriging, which made the recognition of the general background of displacements possible, without the accuracy assessment of $Z^{*}$ value estimation, i.e., the value of $\sigma_{k}$. These maps are also related to 1995 and 2007 and the elevation.

As a result of applying these techniques, clear boundaries of subsiding areas, upthrusting and also horizontal displacements on the examined hydrotechnical object were marked out, which can be interpreted as areas of local deformations of the object, important for the safety of the construction.

The effect of geostatistical research conducted, including the structural analysis, semivariograms modeling, estimating the displacements of the hydrotechnical object, are rich cartographic characteristic (semivariograms, raster maps, block diagrams), which present the spatial visualization of the conducted various analyses of the monitored displacements.

The prepared geostatistical model (3D) of displacement variability (analysed within the area of the dam, during its operating period and including its height) will be useful not only in the correct assessment of displacements and deformations, but it will also make it possible to forecast these phenomena, which is crucial when the operating safety of such constructions is taken into account.
\end{abstract}

Key words: hydrotechnical object, geodetic monitoring, displacements, variation, semivariogram, kriging, quick interpolation techniques

\section{INTRODUCTION}

Because of the complexity of estimating parameters in multidimensional space, special data handling techniques are needed to render the scale and structure of the investigated continuous regionalized phenomena monitored based on the measurements taken in selected points. Due to the great variation in the measured values of the analysed parameter (i.e., a regionalized variable) one cannot use a mathematical function to describe this variable, whereas the classic statistical methods poorly extract the essential information relating to the complex structure of the phenomenon in space. Thanks to the acquisition of reliable information about the distribution of parameters in a meas- 
urement space the investigative methodology used a few tens of years ago to estimate gold $(\mathrm{Au})$ deposits, and recently increasingly often employed in different fields of science and sectors of national economy, can be exploited [7]-[10], [12], [16]-19]. The methodology comprises a set of statistical techniques (based on random function theory) which take the spatial and temporal location of data into account in a measurement data analysis. The premises of geostatistics enable not only a typical statistical approach, but also the qualitative description of measurement data and the presentation of their quantitative-qualitative structure in the investigated measurement space. Geostatistics is a branch of applied (spatial) statistics. Its principal premise are regionalized variables whose values are mutually correlated. Conventional deterministic solutions require many simplifications and the derived models are less accurate. Geostatistical methods offer new possibilities, especially when the geometry and description of the investigated object or area are complicated.

Initially, geostatistics was used only in geology and mining, useful mineral deposit exploration, the evaluation of the spatial characteristics of deposit parameters, and ore content forecasting. The first such studies were conducted in South Africa. Their theoretical foundations had been substantially developed in France. The theory and examples of the application of the methods can be found in many works, e.g., [1]-[3], [5]-[8], [24]. Both theoretical geostatistical research (e.g., in economics) and experimental geostatistical studies in wide spectrum of Earth sciences, such as: geology and hydrology, mining, environmental protection, oceanography, fishery, forestry, geochemistry, metrology, epidemiology, the power industry as well as geodesy and cartography, are being conducted. Many cartographic works dealing with the application of particular geostatistical methods have been published [14], [15]. Studies in the field of environmental protection, dealing with, e.g., the consequences of mining operations, deserve special attention. One should mention estimates of soil, water and air pollution in the direct vicinity of industrial facilities [8]-[13], [18]. Geostatistical techniques are also applicable to various higher and satellite geodesy analyses. The present example is the proposal to estimate the local vector gravitational field of the Earth and to plot (based on the numerical terrain model) maps of gravimetric anomalies, of gravity force gradients and of the density of topographic masses [4], [22]. The combined use of geodetic measurements and results of geological surveys in the analysis of spatially correlated data should help to accurately describe such natural phe- nomena widely extending in space and time as the current movements of the Earth's crust [22], [23], and to model and forecast post-mining deformations.

As an effective instrument for processing and handling the information contained in databases, geostatistics seems to be a proper tool for aiding research in the Geographic Information System (GIS). The developed (2D and 3D) maps enable the quick access to various analytical information [12]-[14].

This paper proposes wider use of geostatistical techniques in the spatial analysis of a displacement field obtained from the geodetic monitoring of areas and buildings subjected to anthropogenic influences, as an example serving a case of the earth dam of a large water reservoir located in the SW part of Poland (the Lubin-Sieroszowice area), i.e., a case in which the modelling and forecasting of the scale of the considered phenomenon is especially relevant.

Selected results of spatial analyses based on geodetic databases containing displacement values registered over many years of monitoring this hydrotechnical structure are reported.

Earlier results of the geostatistical studies of the displacements of the reservoir were presented in conference paper delivered at the Gdańsk University of Technology, at the VII National Scientific Conference: Inspiration-Integration-Implementation in 2014 [20] and in conference paper at the XI Wroclaw ScientificTechnical "Hydro-Engineering Problems", organized by Wroclaw in Świeradów-Zdrój in 2017 [21].

\section{RESEARCH METHODS}

This paper proposes research methods to study phenomena monitored through geodetic measurements. The methods have been applied (on an unprecedented scale) to a macroregion where a large hydrotechnical facility is located. Generally speaking, the methods derive from the investigations of the displacements of various civil engineering structures (chimneys, cooling towers, masts, weirs and hydraulic power plants) conducted in the Water Construction Hydraulic Engineering and Geodesy Unit of the Institute of Geotechnics and Hydrotechnics at Wrocław University of Science and Technology in years 1995-2008. Such structures are being subjected to variable external conditions (e.g., solar radiation and temperature) and loads (the water rise head on weirs, the action of wind on tall structures, etc.).

Thanks to the geodetic monitoring of the hydrotechnical structure, vast amounts of basic empirical 
data, including the results of geodetic surveys of the displacements of check points (CPs) located on the crown and foreland of the structure's earth dam, are available.

The data obtained from the geodetic monitoring have been used to continuously evaluate the behaviour and operational safety of the structure by various supervision and research teams working on the site. Even though geodetic monitoring covers point locations, it is recommended to characterize the distribution of the values of the investigated parameters in the unsampled areas and identify critical subareas with highly varying values of horizontal displacements and subsidences, indicative of the possible occurrence of local deformations of the structure.

Thematic databases, containing values of the coordinates $X, Y$ and $Z$ of the check points (CPs) and their total horizontal displacements: $u x_{c}$ (along the $X$-axis) and $u y_{c}$ (along the $Y$-axis) and resultant displacements $u_{c}\left(u x_{c}\right.$ $+u y_{c}$ ) as well as vertical displacements $u z_{c}$ (along the $Z$-axis), for the years 1990-2009 constituted the basis for spatial analyses of the above parameters variation in $2 \mathrm{D}$ and $3 \mathrm{D}(X-Y, X-Y-Z, X-Y-T)$. Selected results of such studies are shown in the conference paper [20].

The geostatistical investigations were carried out using the isotropic variogram and directional variogram functions, the ordinary kriging estimator and quick interpolation techniques. As a result, averages $Z^{*}$ of the displacements of the hydrotechnical structure were estimated. Prior to the geostatistical computations the data on the original displacements, coming from the geodetic monitoring of the CPs were subjected to analysis.

The spatial analyses were carried out in the following stages:

- preparing 3D databases in two computational versions: (1) coordinates $X, Y, Z$ (elevation) and (2) coordinates $X, Y, T$ (time axis showing displacements of check points on the dam crown and forefield) for the years 1978-2009;

- evaluating the basic statistics and analysing the histograms of the monitored displacements;

- modelling the isotropic variograms of the empirical displacements and their approximation by the means of analytical theoretical functions (geostatistical models);

- cross-validating (verifying) the adopted theoretical models of the isotropic variograms, including evaluating estimation errors in the check points by the means of ordinary (point) kriging;

- estimating displacement averages $Z^{*}$, using ordinary (block) kriging and quick interpolation techniques (the inverse distances squared technique, the linear model kriging and the spline model kriging);

- plotting raster maps of the distributions of estimated displacement averages $Z^{*}$ and estimation standard deviations $\sigma_{k}$ in time space, i.e., in the successive periods of the hydrotechnical structure's service life;

- assessing the scale of the spatial and temporal variation of the displacements (on the different elevation levels of CPs on the structure over the years 1990-2009);

- assessing the effectiveness of the methods of estimating displacement averages $Z^{*}$, including determining mean estimation and interpolation errors.

\section{BASIC STATISTICAL EVALUATION}

Original data on the displacements of the check points on the hydrotechnical structure, monitored in the years 1990-2009 were subjected to basic statistical evaluation. The basic maps show the locations of CPs on the dam's crown and foreland in a particular measurement period, in 2D $(X, Y)$ and 3D $(X, Y, Z)$ (Figs. 1a, 1b).

As an example, the results of estimating the displacement distribution histograms (Figs. 2a, 2b, 2c), including the fit of the Gaussian models to the histograms (Figs. 2d, 2e, 2f), are shown for the year 2007.

The histograms of horizontal displacements $u x_{c}$ and $u y_{c}$ (Figs. 2a, 2b) exhibit right-hand asymmetry (the respective positive skewness coefficients are: $g_{1}=$ +1.008 and $g_{1}=+2.007$ ), but the distribution of displacements $u y_{c}$ in the $\mathrm{E}$ direction is characterized by a twice higher value of coefficient $g_{1}$, which indicates a considerable variation in this parameter and the occurrence of large positive displacements.

The left-hand asymmetry of the histograms of vertical displacements $u z_{c}$ (negative skewness coefficient $\left.g_{1}=-1.189\right)$ expresses the character of the displacements, among which negative values (indicating considerable subsidences of the CPs on the structure) predominate.

The histogram of displacements $u y_{c}$ is much slender (kurtosis: $g_{2}=7.28$ ) (Figs. 2b, 2h), while the other displacement distributions are much flatter.

The basis statistical parameters of the hydrotechnical structure's horizontal and vertical displacements in the CPs, monitored in the years 1990-2009, are presented in Table 1. An analysis of the original displacements for the particular years shows that hori- 

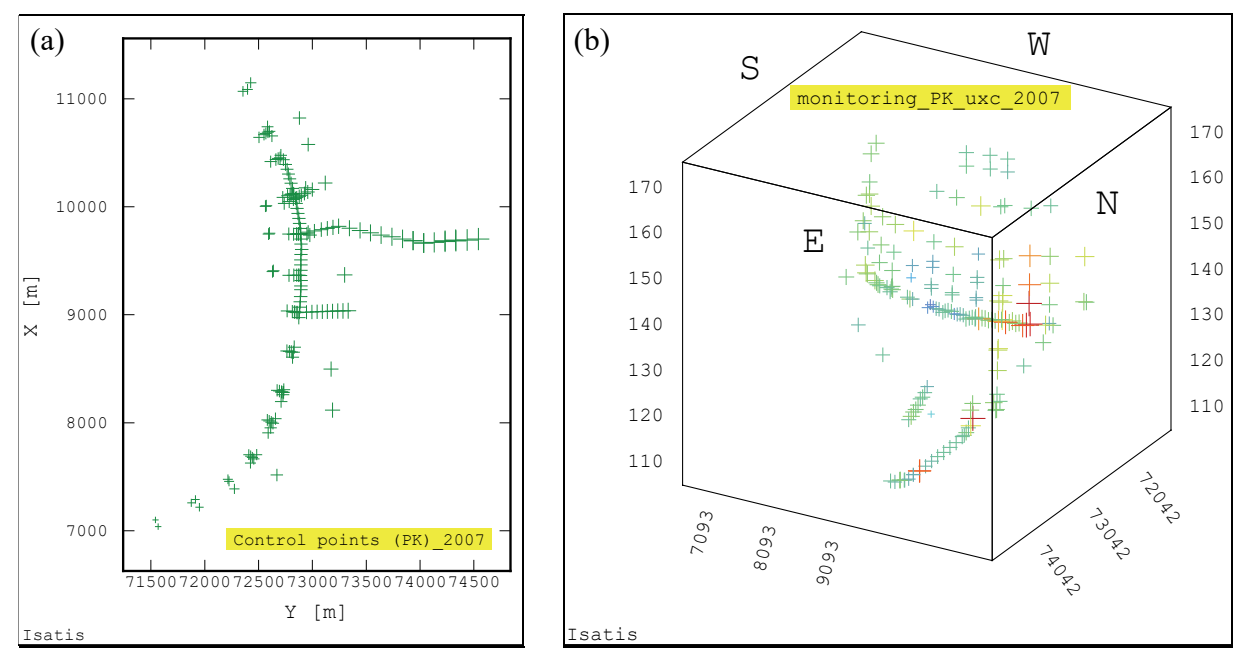

Fig. 1. Base maps of the displacements of the PK control points in the object: (a) in the $X, Y$ flat layout, (b) in the $X, Y, Z$ spatial layout during the sample period of observations (2007)
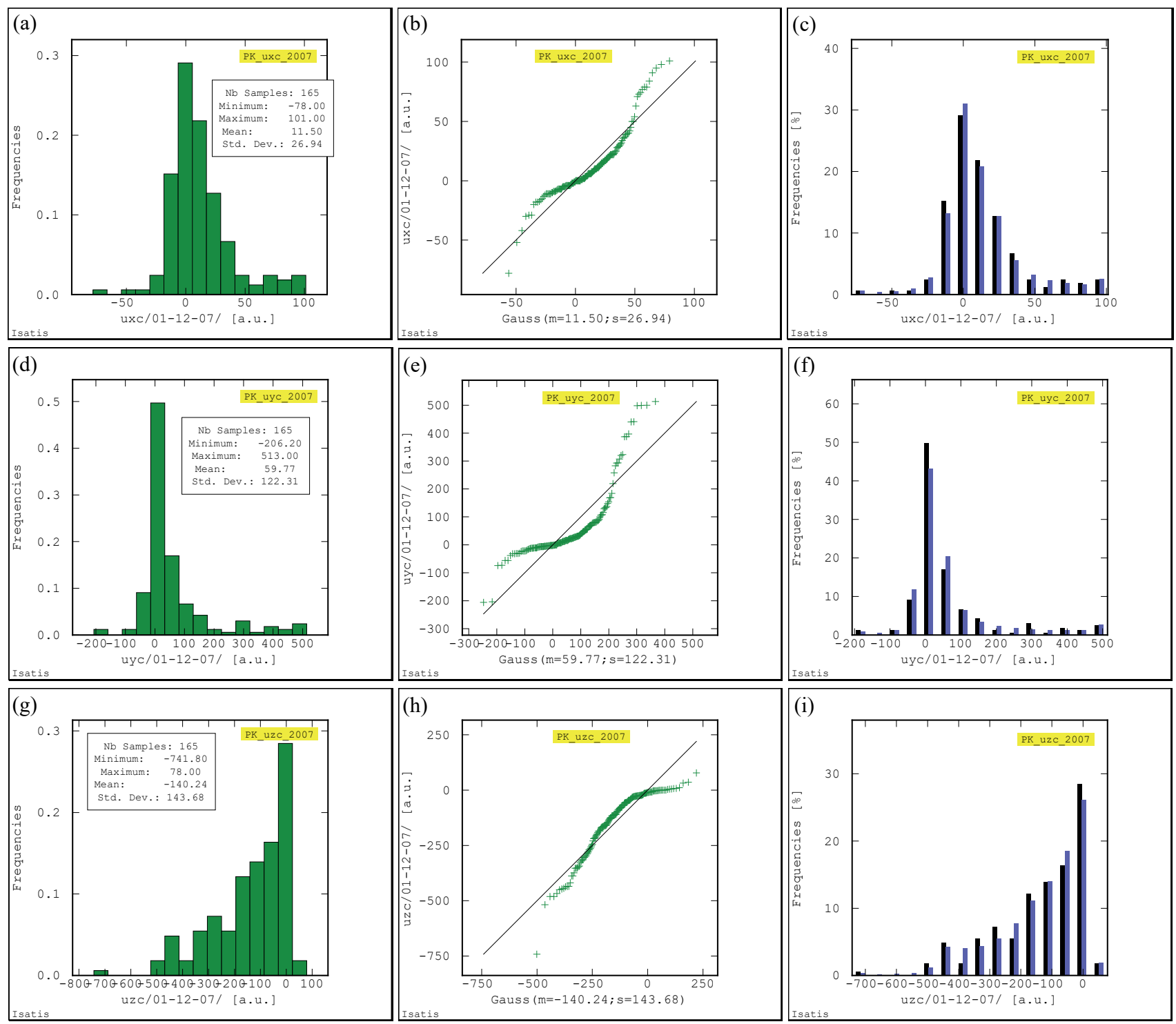

Fig. 2. (a), (b), (c) Histograms of horizontal displacements distributions $u x_{c}$ (skewness coefficient $g_{1}=+1.008$; kurtosis coefficient $g_{2}=5.38$ ), $u y_{c}\left(g_{1}=+2.007 ; g_{2}=7.28\right)$ and vertical displacements $u z_{c}\left(g_{1}=-1.189 ; g_{2}=4.18\right) ;(\mathrm{d})$, (e), (f) The results of Gaussian model fitting to $u x_{c}$, $u y_{c}$ and $u z_{c}$ displacements histograms; (g), (h), (i) Histograms of $u x_{c}, u y_{c}$ and $u_{c}$ displacements distributions with the fitted theoretical models (2007) 
Table 1. Basic statistics of monitored displacements of the hydrotechnical facility

\begin{tabular}{|c|c|c|c|c|c|c|c|}
\hline \multicolumn{2}{|c|}{$\begin{array}{c}\text { Analyzed variable } \\
\text { in years }\end{array}$} & \multirow{2}{*}{$\begin{array}{c}\text { Size } \\
n \\
79\end{array}$} & \multirow{2}{*}{$\begin{array}{c}\begin{array}{c}\text { Mean } \\
\text { value } \\
\text { valu } \\
X_{\text {sr }}[\text { a.u. }]\end{array} \\
5.57\end{array}$} & \multirow{2}{*}{$\begin{array}{c}\begin{array}{c}\text { Minimal } \\
\text { value }\end{array} \\
X_{\min }[\text { a.u. }] \\
-8.00\end{array}$} & \multirow{2}{*}{$\begin{array}{c}\begin{array}{c}\text { Maximal } \\
\max .\end{array} \\
X_{\max }[\text { a.u.] } \\
27.00\end{array}$} & \multirow{2}{*}{$\begin{array}{c}\begin{array}{c}\text { Standard } \\
\text { deviation } \\
S \text { [a.u.] }\end{array} \\
8.54\end{array}$} & \multirow{2}{*}{$\begin{array}{c}\text { Variability } \\
\text { coefficient } \\
V[\%] \\
153\end{array}$} \\
\hline \multirow{9}{*}{ 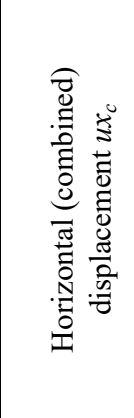 } & 1990 & & & & & & \\
\hline & 1995 & 110 & -8.73 & -56.00 & 54.00 & 18.70 & -214 \\
\hline & 2000 & 131 & 4.78 & -31.00 & 40.00 & 14.99 & 314 \\
\hline & 2003 & 153 & 4.37 & -58.00 & 115.00 & 34.06 & 779 \\
\hline & 2005 & 156 & 3.05 & -31.00 & 56.00 & 15.39 & 504 \\
\hline & 2006 & 158 & 36.54 & -54.00 & 263.00 & 61.74 & 169 \\
\hline & 2007 & 165 & 11.79 & -33.00 & 86.00 & 20.82 & 176 \\
\hline & 2008 & 145 & 14.08 & -74.00 & 104.00 & 25.80 & 183 \\
\hline & 2009 & 161 & 13.11 & -72.00 & 131.94 & 27.37 & 209 \\
\hline \multirow{9}{*}{ 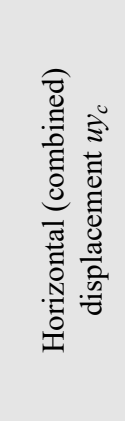 } & 1990 & 79 & 43.44 & -33.00 & 366.00 & 82.79 & 190 \\
\hline & 1995 & 110 & 15.02 & -36.00 & 93.00 & 22.83 & 152 \\
\hline & 2000 & 131 & 56.16 & -29.00 & 437.00 & 97.47 & 174 \\
\hline & 2003 & 153 & 10.02 & -43.00 & 97.00 & 26.06 & 260 \\
\hline & 2005 & 156 & 59.59 & -204.40 & 489.00 & 116.77 & 196 \\
\hline & 2006 & 158 & 11.50 & -78.00 & 101.00 & 26.94 & 234 \\
\hline & 2007 & 165 & 59.77 & -206.20 & 513.00 & 122.31 & 205 \\
\hline & 2008 & 145 & 54.61 & -206.20 & 539.20 & 106.13 & 194 \\
\hline & 2009 & 161 & 63.24 & -206.20 & 581.20 & 115.88 & 183 \\
\hline \multirow{9}{*}{ 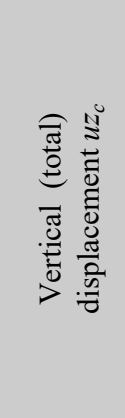 } & 1990 & 79 & -111.71 & -884.50 & 0.00 & 146.70 & -131 \\
\hline & 1995 & 110 & -94.85 & -395.70 & 17.20 & 100.36 & -106 \\
\hline & 2000 & 131 & -117.11 & -467.40 & 25.90 & 117.49 & -100 \\
\hline & 2003 & 153 & -115.78 & -490.30 & 33.20 & 126.66 & -109 \\
\hline & 2005 & 156 & -119.74 & -501.10 & 65.00 & 130.56 & -109 \\
\hline & 2006 & 158 & -130.78 & -507.10 & 78.00 & 134.42 & -103 \\
\hline & 2007 & 165 & -140.24 & -741.80 & 78.00 & 143.68 & -102 \\
\hline & 2008 & 145 & -130.03 & -797.29 & 41.20 & 137.36 & -106 \\
\hline & 2009 & 161 & -138.62 & -852.45 & 21.98 & 139.89 & -101 \\
\hline
\end{tabular}

zontal displacements $u x_{c}$ assumed mainly positive values (in the $\mathrm{N}$ direction), ranging from +27.0 a.u. (arbitrary units) in 1990 to +263.0 a.u. in 2006. The negative values of the displacements (in the $\mathrm{S}$ direction) ranged from -8.0 a.u. in 1990 to -74.0 a.u. in 2008. In the case of horizontal displacements $u y_{c}$, positive values predominated (in the $\mathrm{E}$ direction), ranging from +93.0 a.u. in 1995 to +581.2 a.u. in 2009 . The negative values of the displacements (in the $\mathrm{W}$ direction) were lower, ranging from -29.0 a.u. in 2000 to -206.2 a.u. in 2009 . The high values of negative vertical displacements $u z_{c}$ (subsidences of the CPs) stand out, particularly in the years 1990, 2007, 2008 and 2009, ranging from -884.5 a.u. (1990) to -852.4 a.u. (2009). The positive values of $u z_{c}$ (uplifts of the CPs) were low, ranging from 0,0 a.u. in 1990 to +78.0 a.u. in 2007 .

A high variation in the displacements over the years, as evidenced by the high variation coefficients $(V)$, is observed. In the case of total horizontal displacements $u x_{c}$, particularly high values of $V(504-779 \%)$ were obtained for the years 2003 and 2005, which can be ascribed to the high maximum displacement values. Coefficients $V$ were also high for total horizontal displacements $u y_{c}$ in the years 2003 and 2006, but they reached lower values (234-260\%) than for displacements $u x_{c}$. High values of horizontal displacements $u y_{c}$ were recorded in many of the years considered (2005, 2007-2009). Much lower variation coefficients $V$ (about 100-130\%) were noted for total horizontal displacements $u z_{c}$ over the years considered, but they also indicated a considerable variation in subsidences.

\section{MODELLING OF DISPLACEMENT SEMIVARIOGRAMS}

The principal stage in geostatistical research is a structural (variographic) analysis of the variation of 
a particular parameter, performed using the variogram function [1], [6]-[8], [24]. Empirical displacement variograms are calculated and their shapes are approximated with theoretical functions. As a result of the fitting, the so-called geostatistical models reflecting the structure of the variation in the investigated regionalized variables (horizontal and vertical displacements) are obtained. Thanks to the approximation the determination of the values of the adopted models' geostatistical parameters is possible.

The form of the variogram function for a discrete regular survey grid is calculated from G. Matheron's formula:

$$
2 \gamma(h)=\frac{1}{n_{k}} \sum_{i=1}^{n_{h}}\left(Z_{\vec{h}+i}-Z_{i}\right)^{2}
$$

where:

$2 \gamma(h)$ - a variogram,

$\gamma(h)$ - a semivariogram (half-variogram),

$Z_{i}, Z_{\vec{h}+i}$ - values of the regionalized variable in points spaced at a distance equal to vector $\vec{h}$,

$n_{h}$ - the number of survey points spaced at a distance equal to vector $\vec{h}$.

As a part of this research the isotropic semivariograms of total horizontal displacements $u x_{c}$ and $u y_{c}$, resultant displacements $u_{c}\left(u x_{c}+u y_{c}\right)$ and vertical displacements $u z_{c}$ were modelled, which means that all the point data from the monitoring of displacements were taken into account.

In most cases, complex theoretical model structures (Tables 2-3) were adopted. Figure 3 shows exemplary isotropic semivariograms of resultant horizontal displacements $u_{c}$ and vertical displacements $u z_{c}$ for monitoring covering the years: 1995, 2005 and 2007, together with their theoretical models. The parameters of the models, i.e., sill variances $C=C_{o}+C^{\prime}$ and influence (correlation) ranges $a$ for the displacements registered in the years: 1995, 2005 and 2007, are shown in Tables 2-4.

The isotropic displacement variograms differ in their patterns. The semivariograms of horizontal displacements $u_{c}$ and vertical displacements $u z_{c}$, monitored in 1995, show a clear tendency for function $\gamma(h)$ to increase with distance $h$ (Figs. 3a, 3b), particularly visible in the case of subsidences $u z_{c}$. No such trend can be seen in the semivariograms of these displacements, calculated for the years 2005 and 2007 (Figs. 3c, $3 \mathrm{~d}, 3 \mathrm{e}, 3 \mathrm{f})$.

The values of displacements $u_{c}$ and $u z_{c}$ were found to be highly correlated in all the considered years, which means long influence range $a$, amounting to several hundred a.u., varying from about 200 a.u. to 950
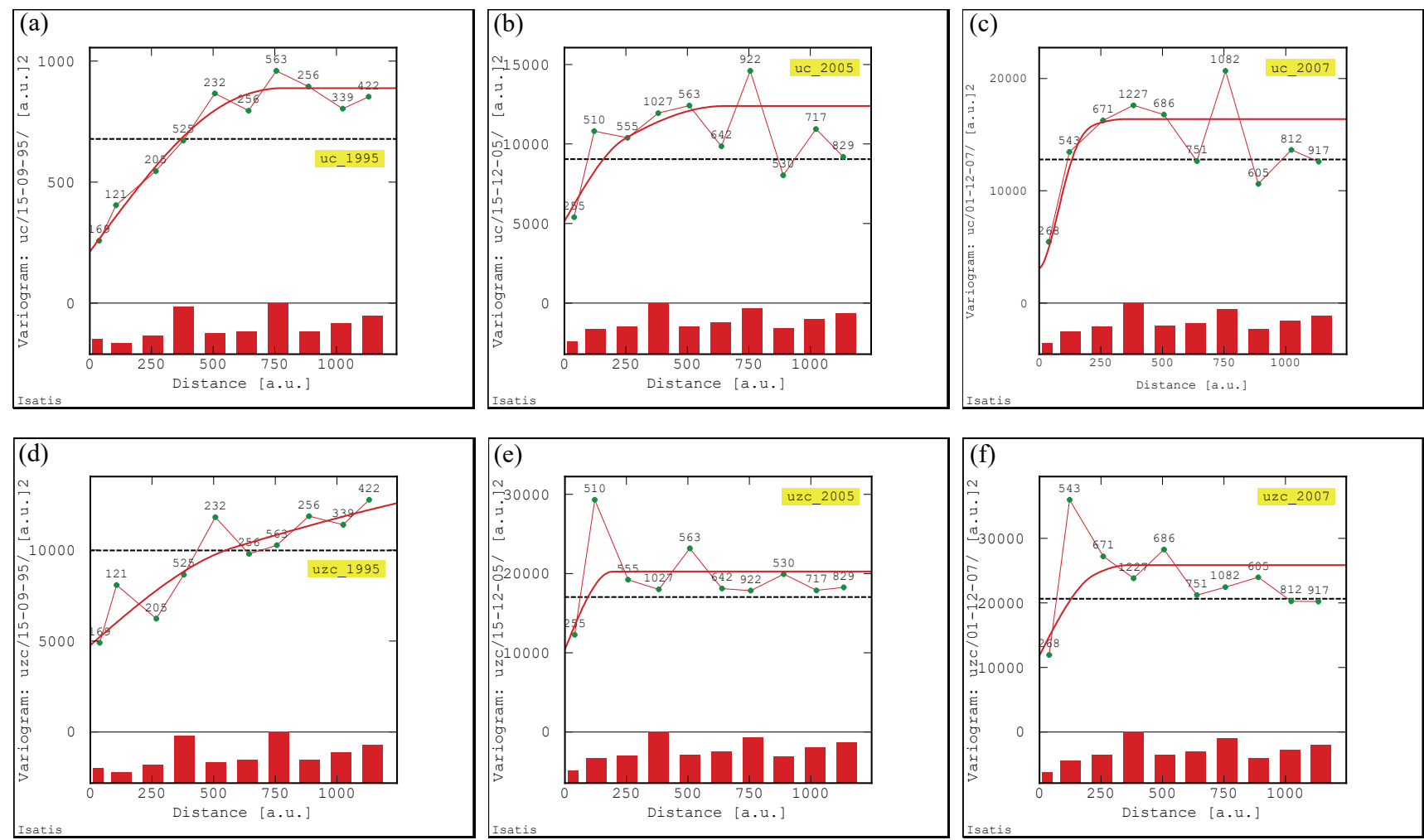

Fig. 3. Isotropic empirical semivariograms of total horizontal displacements $u_{c}\left(u x_{c}+u y_{c}\right)$ and vertical displacements $u z_{c}$, approximated by the means of theoretical models: (a), (b) 1995; (c), (d) 2005; (e), (f) 2007 
(Tables 2-4). Only in the case of displacements $u z_{c}$ for 1995 and $u y_{c}$ for 2007 long influence range $a$, evident in the semivariogram reached over 2400 a.u. and 1200 a.u., indicating large-scale changes along vertical axis $(Z)$ and in the direction $(\mathrm{E})$.

More pronounced nugget effect $C_{0}$ and higher values of sill variance $C$ for displacements $u_{c}, u y_{c}$ and $u z_{c}$ (Tables 3 and 4 ) are reflected in the exemplary semi- variograms, in particular, for the $u z_{c}$, showing sharp variations in parameters $u_{c}$ and $u z_{c}$ in the years 2005 and 2007 (Figs. 3c, 3d, 3e, 3f). The much higher value of nugget effect $C_{0}$ in the years 2005 and 2007, compared to 1995 , indicates a higher (very high) percentage of the random component in the total variance $(C)$ in displacement values, which means hard to predict displacements.

Table 2. Geostatistical parameters of theoretical models of empirical semivariograms of displacements for the Earth dam of hydrotechnical facility, 1995

\begin{tabular}{|c|c|c|c|c|c|}
\hline $\begin{array}{c}\text { Analyzed (total) } \\
\text { displacement } \\
1995\end{array}$ & $\begin{array}{c}\text { Nugget } \\
\text { effect } \\
C_{0}\end{array}$ & $\begin{array}{c}\text { Partial } \\
\text { variance } \\
C^{\prime}\end{array}$ & $\begin{array}{c}\text { Total } \\
\text { sill } \\
\text { variance } \\
C=C_{0}+C^{\prime}\end{array}$ & $\begin{array}{c}\text { Range } \\
\text { of influence } \\
a \text { [a.u.] }\end{array}$ & $\begin{array}{c}\text { Type of } \\
\text { model }\end{array}$ \\
\hline $\begin{array}{c}\text { Horizontal } \\
u x_{c} \\
\text { [a.u.] }\end{array}$ & 97.348 & $\begin{array}{c}9.407 \\
81.883\end{array}$ & 188.638 & $\begin{array}{l}508.83 \\
508.83\end{array}$ & $\begin{array}{c}\text { spherical, } \\
\text { gamma, } \\
\text { nugget } \\
\text { effect }\end{array}$ \\
\hline $\begin{array}{c}\text { Horizontal } \\
u y_{c} \\
\text { [a.u.] }\end{array}$ & 270.513 & $\begin{array}{l}1614.540 \\
1672.190\end{array}$ & 3557.243 & $\begin{array}{l}395.95 \\
956.49\end{array}$ & $\begin{array}{c}\text { Bessel-K, } \\
\text { Bessel-J, } \\
\text { nugget } \\
\text { effect }\end{array}$ \\
\hline $\begin{array}{c}\text { Horizontal } \\
\text { combined } \\
u_{c}\left(u x_{c}+u y_{c}\right) \\
\text { [a.u.] } \\
\end{array}$ & 212.753 & $\begin{array}{l}545.983 \\
129.124\end{array}$ & 887.860 & $\begin{array}{l}778.49 \\
586.89\end{array}$ & $\begin{array}{c}\text { spherical, } \\
\text { spherical, } \\
\text { nugget } \\
\text { effect }\end{array}$ \\
\hline $\begin{array}{c}\text { Vertical } \\
\qquad u z_{c} \\
\text { [a.u.] }\end{array}$ & 4779.967 & $\begin{array}{l}6989.701 \\
2898.825\end{array}$ & 14668.493 & $\begin{array}{c}2424.79 \\
585.96\end{array}$ & $\begin{array}{c}\text { spherical, } \\
\text { spherical, } \\
\text { nugget } \\
\text { effect }\end{array}$ \\
\hline
\end{tabular}

Table 3. Geostatistical parameters of theoretical models of isotropic empirical semivariograms of displacements for the Earth dam of hydrotechnical facility, 2005

\begin{tabular}{|c|c|c|c|c|c|}
\hline $\begin{array}{l}\text { Analyzed (total) } \\
\text { displacement } \\
2005\end{array}$ & $\begin{array}{c}\text { Nugget } \\
\text { effect } \\
C_{0}\end{array}$ & $\begin{array}{c}\text { Partial } \\
\text { variance } \\
C^{\prime}\end{array}$ & $\begin{array}{c}\text { Total } \\
\text { sill } \\
\text { variance } \\
C=C_{0}+C^{\prime}\end{array}$ & $\begin{array}{c}\text { Range } \\
\text { of influence } \\
a \text { [a.u.] }\end{array}$ & $\begin{array}{c}\text { Type } \\
\text { of model }\end{array}$ \\
\hline $\begin{array}{c}\text { Horizontal } \\
u x_{c} \\
\text { [a.u.] }\end{array}$ & 265.908 & $\begin{array}{l}213.580 \\
109.025\end{array}$ & 588.513 & $\begin{array}{l}508.84 \\
508.84\end{array}$ & $\begin{array}{c}\text { Cauchy, } \\
\text { gamma, } \\
\text { nugget } \\
\text { effect }\end{array}$ \\
\hline $\begin{array}{c}\text { Horizontal } \\
u y_{c} \\
\text { [a.u.] } \\
\end{array}$ & 4532.070 & 8968.060 & 13500.130 & 579.14 & $\begin{array}{c}\text { exponential, } \\
\text { nugget } \\
\text { effect }\end{array}$ \\
\hline $\begin{array}{c}\text { Horizontal } \\
\text { combined } \\
u_{c}\left(u x_{c}+u y_{c}\right) \text { [a.u.] }\end{array}$ & 5144.815 & $\begin{array}{l}2787.990 \\
4458.197\end{array}$ & 12391.002 & $\begin{array}{l}248.68 \\
651.03\end{array}$ & $\begin{array}{l}\text { spherical, } \\
\text { spherical, } \\
\text { nugget } \\
\text { effect }\end{array}$ \\
\hline $\begin{array}{c}\text { Vertical } \\
u z_{c} \\
\text { [a.u.] }\end{array}$ & 10435.454 & $\begin{array}{c}9748.588 \\
81.494\end{array}$ & 20265.536 & $\begin{array}{l}192.11 \\
412.27\end{array}$ & $\begin{array}{l}\text { spherical, } \\
\text { spherical, } \\
\text { nugget } \\
\text { effect }\end{array}$ \\
\hline
\end{tabular}


Table 4. Geostatistical parameters of theoretical models of isotropic empirical semivariograms of displacements for the Earth dam of hydrotechnical facility, 2007

\begin{tabular}{|c|c|c|c|c|c|}
\hline $\begin{array}{c}\text { Analyzed (total) } \\
\text { displacement } \\
2007\end{array}$ & $\begin{array}{c}\text { Nugget } \\
\text { effect } \\
C_{0}\end{array}$ & $\begin{array}{c}\text { Partial } \\
\text { variance } \\
C^{\prime}\end{array}$ & $\begin{array}{c}\text { Total sill } \\
\text { variance } \\
C^{\prime} C_{0}+C^{\prime}\end{array}$ & $\begin{array}{c}\text { Range } \\
\text { of influence } \\
a \text { [a.u.] }\end{array}$ & $\begin{array}{c}\text { Type } \\
\text { of model }\end{array}$ \\
\hline $\begin{array}{c}\text { Horizontal } \\
u x_{c} \\
\text { [a.u.] }\end{array}$ & 325.415 & $\begin{array}{c}227.564 \\
257.448 \\
187.151\end{array}$ & 997.578 & $\begin{array}{c}508.85 \\
508.85 \\
508.85\end{array}$ & $\begin{array}{c}\text { exponential, } \\
\text { Bessel-J, } \\
\text { Cauchy, } \\
\text { nugget effect }\end{array}$ \\
\hline $\begin{array}{c}\text { Horizontal } \\
u y_{c} \\
\text { [a.u.] }\end{array}$ & 3115.240 & $\begin{array}{c}15219.500 \\
1100.210\end{array}$ & 19434.950 & $\begin{array}{c}356.56 \\
1203.92\end{array}$ & $\begin{array}{c}\text { exponential, } \\
\text { spherical, } \\
\text { nugget effect }\end{array}$ \\
\hline $\begin{array}{c}\text { Horizontal } \\
\text { combined } \\
u_{c}\left(u x_{c}+u y_{c} \text { ) [a.u.] }\right.\end{array}$ & 3084.305 & 10297.345 & 15750.355 & 312.02 & $\begin{array}{c}\text { cubic, } \\
\text { spherical, } \\
\text { nugget effect }\end{array}$ \\
\hline $\begin{array}{c}\text { Vertical } \\
u z_{c} \\
\text { [a.u.] }\end{array}$ & 11879.102 & 6439.963 & 25867.149 & 223.84 & $\begin{array}{c}\text { spherical, } \\
\text { spherical, } \\
\text { nugget effect }\end{array}$ \\
\hline
\end{tabular}

\section{RESULTS OF CROSS VALIDATION}

The correctness of the fit between the theoretical models and the empirical semivariograms was verified by cross-validation, consisting in the use of ordinary (point) kriging to calculate estimated averages $Z^{*}$ of displacement in each check point, assuming a unique or moving kriging neighbourhood. In the considered case, data representing the whole sample (point) popu-

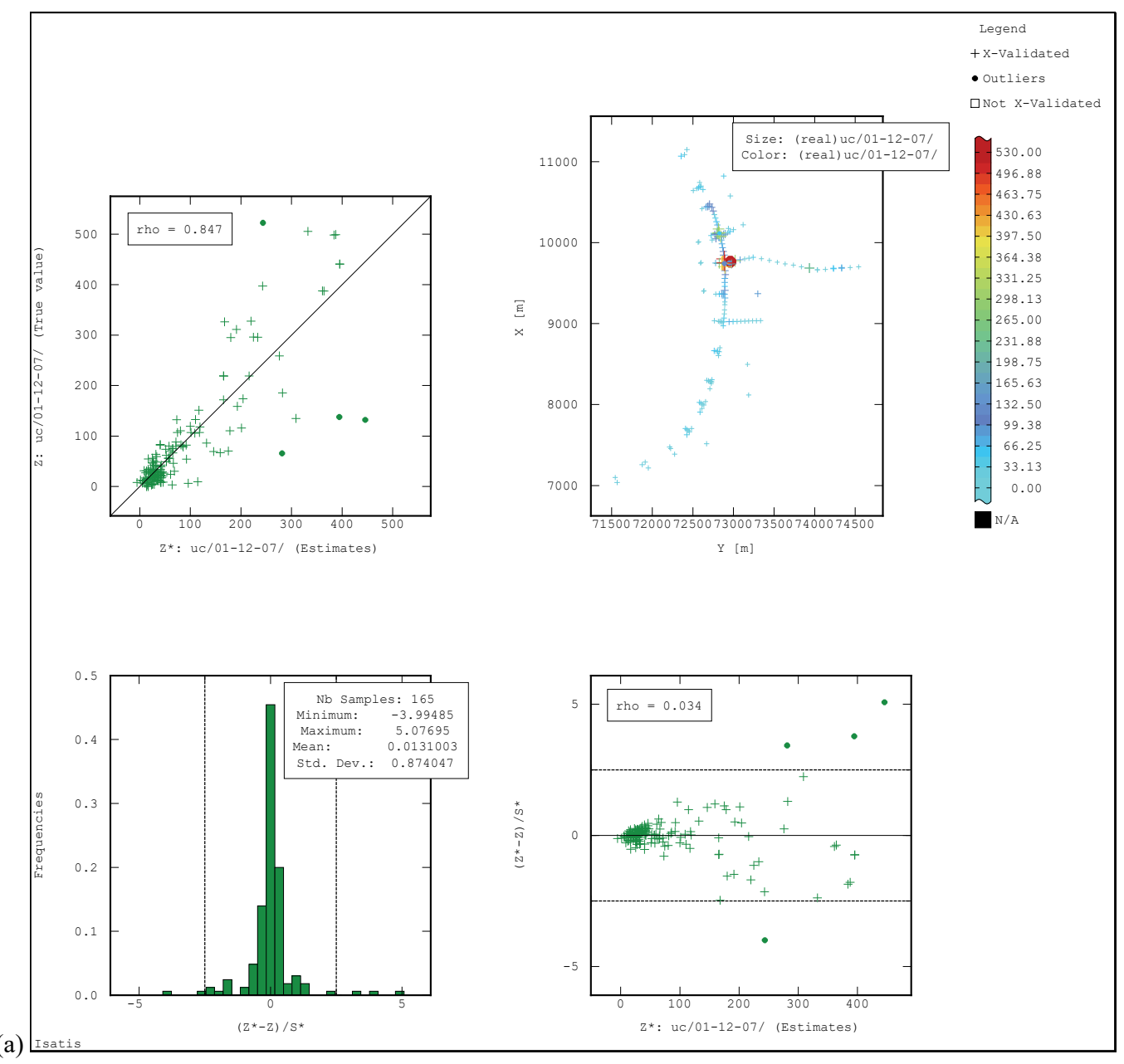




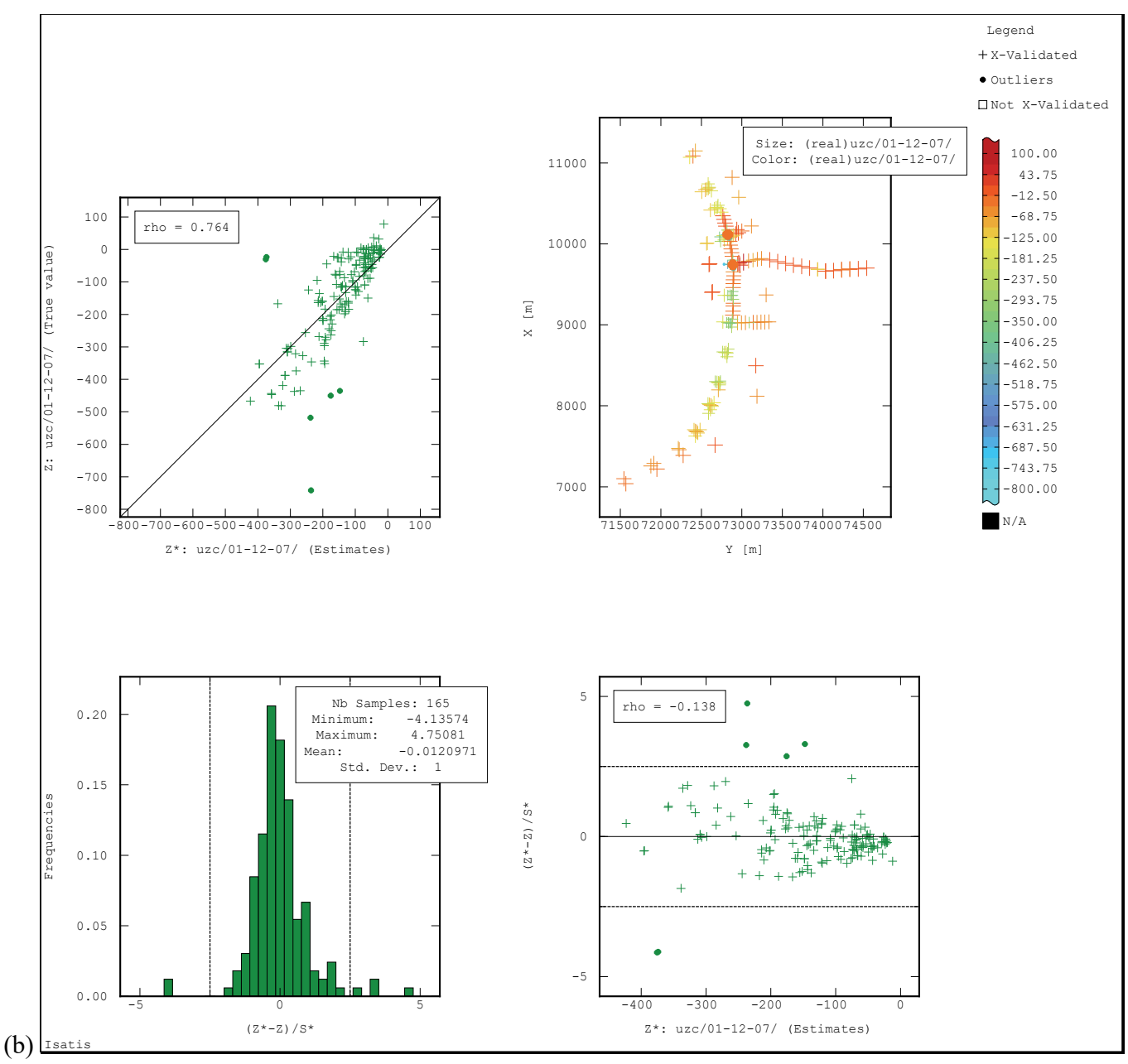

Fig. 4. The results of the cross-validation for the assumed theoretical model of the isotropic empirical semivariogram of total horizontal displacements $u_{c}, 2007$ (a) and total vertical displacements $u z_{c}, 2007$; (b), for the earth dam of the analyzed facility, using the unique "kriging" neighborhood: the base map of the analyzed displacements; the graph of the dependence of the actual (true) values of $Z$ and estimated values $Z^{*}$; the histogram of standardized error values distribution $\left(Z^{*}-Z\right) / S^{*}$; graph of dependence of standardized error values $\left(Z^{*}-Z\right) / S^{*}$ and estimated averages $Z^{*}$

lation, i.e., a unique neighbourhood, were taken into account when estimating averages $Z^{*}$. Mean estimation errors $\left(Z^{*}-Z\right)$, expressed in the form of standardized mean errors $\left(Z^{*}-Z\right) / S(S-$ standard deviation), were determined by comparing the $Z^{*}$ values with the original $Z$ values in the CPs. As an example, the distributions of the standardized errors and the results of fitting the $Z^{*}$ values to the $Z$ values for resultant horizontal displacements $u_{c}$ and vertical displacements $u z_{c}$, measured in 2007, are shown in Figs. $4 \mathrm{a}$ and $4 \mathrm{~b}$.

Tables 5 and 6 present exemplary cross validation results for the years 1995 and 2007. The calculations were based on test data for the number of check points: $n=110$ and $n=165$. The variances of the standardized errors did not exceed the assumed standardized value of 1.0 (Tables 5 and 6), which indicates that the approximation was performed correctly, i.e., proper theoretical models were adopted to represent the shapes of the empirical displacement variograms.

The results of the cross-validation calculations should be taken into account in the further parameter (displacement) estimation procedures.

The indication of the correctness of fit between the theoretical models and the empirical semivariograms were mostly the high coefficients of correlation $(r)$ between the original $Z$ values and the estimated $Z^{*}$ values, determined for the years 1990-2009 (Table 7).

From 2005 the correlation coefficients $(r)$ generally tended to increase for all kinds of displacements. This can be explained by the increasing number of check points on the hydrotechnical structure in the years that followed, which certainly could affect the results of calculations (higher values of coefficient $r$ ). As the amount of measurement data increases, so do the possibilities of modelling the empirical semivariograms of displacements. 
Table 5. The results of the calculations connected with cross-validation procedure for the assumed theoretical models of isotropic empirical semivariograms of displacemenets for the Earth dam of the analyzed hydrotechnical facility, using the unique kriging neighborhood; tested data, 1995

\begin{tabular}{|c|c|c|c|c|c|}
\hline \multirow{2}{*}{$\begin{array}{c}\text { Analyzed } \\
\text { parameter }\end{array}$} & $\begin{array}{c}\text { Size } \\
n\end{array}$ & $\begin{array}{c}\text { Tested data_1995 (unique kriging neighborhood) } \\
\text { everor }\end{array}$ & $\begin{array}{c}\text { error } \\
\text { variance }\end{array}$ & $\begin{array}{c}\text { standardized } \\
\text { error } \\
\text { average }\end{array}$ & $\begin{array}{c}\text { standardized } \\
\text { error } \\
\text { variance }\end{array}$ \\
\hline $\begin{array}{c}\text { Horizontal (total) } \\
\text { displacement } \\
u x_{c} \text { [a.u.] }\end{array}$ & 110 & -0.142 & 150.519 & -0.006 & 0.899 \\
\hline $\begin{array}{c}\text { Horizontal (total) } \\
\text { displacement } \\
u y_{c} \text { [a.u.] }\end{array}$ & 110 & 0.131 & 362.599 & 0.004 & 1.000 \\
\hline $\begin{array}{c}\text { Combined (total) } \\
\text { displacement } \\
u_{c}\left(u x_{c}+u y_{c} \text { ) [a.u.] }\right.\end{array}$ & 110 & 0.600 & 322.910 & 0.014 & 1.000 \\
\hline $\begin{array}{c}\text { Vertical (total) } \\
\text { displacement } \\
u z_{c} \text { [a.u.] }\end{array}$ & 111 & -2.329 & 3564.138 & -0.014 & 0.588 \\
\hline
\end{tabular}

Table 6. The results of calculations connected with cross-validation procedure for the assumed theoretical models of isotropic empirical semivariograms of displacements for the dam of the analyzed hydrotechnical facility, using the unique kriging neighborhood; tested data, 2007

\begin{tabular}{|c|c|c|c|c|c|}
\hline \multirow{2}{*}{$\begin{array}{c}\text { Analyzed } \\
\text { parameter }\end{array}$} & $\begin{array}{c}\text { Size } \\
n\end{array}$ & $\begin{array}{c}\text { Error } \\
\text { average }\end{array}$ & $\begin{array}{c}\text { Error } \\
\text { variance }\end{array}$ & $\begin{array}{c}\text { Standardized } \\
\text { error } \\
\text { average }\end{array}$ & $\begin{array}{c}\text { Standardized } \\
\text { error } \\
\text { variance }\end{array}$ \\
\cline { 3 - 6 } & 165 & 0.379 & 401.965 & 0.008 & 0.823 \\
\hline $\begin{array}{c}\text { Horizontal (total) } \\
\text { displacement } \\
u x_{c} \text { [a.u.] }\end{array}$ & 165 & 1.733 & 3862.659 & 0.010 & 0.551 \\
\hline $\begin{array}{c}\text { Horizontal (total) } \\
\text { displacement } \\
u y_{c} \text { [a.u.] }\end{array}$ & 165 & 2.330 & 3863.930 & 0.013 & 0.554 \\
\hline $\begin{array}{c}\text { Combined (total) } \\
\text { displacement } \\
u_{c}\left(u x_{c}+u y_{c} \text { ) [a.u.] }\right.\end{array}$ & 165 & -2.729 & 9196.064 & -0.009 & 0.475 \\
\hline $\begin{array}{c}\text { Vertical (total) } \\
\text { displacement } \\
u z_{c} \text { [a.u.] }\end{array}$ & 16907 (unique kriging neighborhood) \\
\hline
\end{tabular}

Table 7. The results of cross-validation; correlation coefficients $r$ study between values of original values $Z$ and estimated averages $Z^{*}$ of displacements, in the years of 1990-2009

\begin{tabular}{|c|c|c|c|c|c|c|c|c|c|}
\hline \multirow{2}{*}{$\begin{array}{c}\text { Analyzed } \\
\text { parameter }\end{array}$} & \multicolumn{7}{|c|}{$\begin{array}{c}\text { Correlation coefficients } r \text { between original values of displacements } Z \\
\text { and estimated values } Z * \text { in analyzed years }\end{array}$} \\
\cline { 2 - 11 } & 1990 & 1995 & 2000 & 2003 & 2005 & 2006 & 2007 & 2008 & 2009 \\
\hline $\begin{array}{c}\text { Horizontal (total) } \\
\text { displacement } u x_{c} \text { [a.u.] }\end{array}$ & 0.53 & 0.61 & 0.47 & 0.60 & 0.67 & 0.73 & 0.67 & 0.73 & 0.75 \\
\hline $\begin{array}{c}\text { Horizontal (total) } \\
\text { displacement } u y_{c} \text { [a.u.] }\end{array}$ & 0.61 & 0.86 & 0.67 & 0.71 & 0.79 & 0.85 & 0.86 & 0.88 & 0.89 \\
\hline $\begin{array}{c}\text { Horizontal (combined) } \\
\text { displacement } u_{c}\left(u x_{c}+u y_{c} \text { ) [a.u.] }\right.\end{array}$ & 0.33 & 0.82 & 0.71 & 0.69 & 0.78 & 0.82 & 0.85 & 0.86 & 0.88 \\
\hline $\begin{array}{c}\text { Vertical (total) } \\
\text { displacement } u z_{c} \text { [a.u.] }\end{array}$ & 0.55 & 0.81 & 0.64 & 0.69 & 0.73 & 0.76 & 0.76 & 0.81 & 0.86 \\
\hline
\end{tabular}




\section{ESTIMATION TECHNIQUES}

The following techniques of estimating and interpolating displacement averages $Z^{*}$ were used in the spatial analyses:

- ordinary block kriging,

- quick interpolation techniques (the inverse distances squared technique, the linear model kriging and the spline model kriging).

Unlike the quick interpolation techniques, estimation by the means of the ordinary block-kriging method is based on the variogram function used to investigate the spatial structure of the displacements. The modelling of variograms by the means of theoretical functions leads to the calculation of the geostatistical parameters describing the correlation of the investigated variables, i.e., influences range $a$, sill variance $C$ and nugget effect $C_{0}$. Based on this the random variable share and the non-random variable share in total variance $C$ of the considered kind of displacements can be determined [1], [6]-[8], [24].

The general linear weighted estimator of the mean value of a parameter has the form:

$$
Z^{*}\left(x_{0}\right)=\sum_{i=1}^{n} w_{i} Z\left(x_{i}\right)
$$

where $w_{i}$-a kriging weight coefficient (the weight of the $i$-th observation (measurement)),

The ordinary block kriging variance is expressed by the formula:

$$
\sigma_{k}^{2}=\lambda+\sum_{i=1}^{n} w_{i} \cdot \bar{\gamma}\left(S_{i}, A\right)-\bar{\gamma}(A, A)
$$

where:

$\bar{\gamma}\left(S_{i}, A\right)$ - the mean semivariogram value between check (estimating) points $S_{i}$ and points in calculation block $A$ within which the mean parameter value is estimated,

$\bar{\gamma}(A, A)$ - the mean semivariogram value between all the check point combinations in calculation block $A$,

\section{$\lambda$ - a Lagrange multiplier.}

The ordinary point kriging variance is expressed by the formula:

$$
\sigma_{k}^{2}\left(x_{0}\right)=\lambda+\sum_{i=1}^{n} w_{i} \gamma\left(x_{i}, x_{0}\right)
$$

where: $\lambda$ - a Lagrange multiplier,

$\gamma\left(x_{i}, x_{0}\right)$ - the mean semivariogram value between check points $x_{i}$ and estimated position $x_{0}$ during estimation.

For point-kriging the formula is simpler, i.e., without term $\bar{\gamma}(A, A)$, since the semivariogram value in the point is equal to zero.

Displacement averages $Z^{*}$ were estimated and the accuracy of the estimates of this variable in the nodes of the adopted elementary grid was evaluated using the selected estimation and interpolation techniques [7]. In addition to averages $Z^{*}$, the estimation techniques yielded estimation standard deviation $\left(\sigma_{k}\right)$ values. In the case of the quick interpolation techniques, only interpolated $Z^{*}$ values were calculated.

A spatial (3D) elementary grid was adopted for the CPs on the hydrotechnical structure. The elementary grid block dimensions were: $5+0$ a.u. along the $X$-axis, 100 a.u. along the $Y$-axis and 1 a.u. along the $Z$-axis. The number of elementary blocks amounted to 52, 82 and 60 for $X$-, $Y$ - and $Z$-axes, respectively. The total number of elementary blocks taken into account in the (3D) estimation of averages $Z^{*}$ was $n=255840$. The unique kriging neighbourhood (the area of search for check points) with regular $10 \times 10 \times 5$ block discretization was adopted.

\subsection{ESTIMATION USING ORDINARY KRIGING}

After applying of estimating techniques the ordinary block-kriging technique was used to estimate displacement averages $Z^{*}$ and estimation errors (estimation standard deviations $\sigma_{k}$ ) in the nodes of the adopted elementary grid, taking into account the values of the geostatistical semivariogram models' parameters.

The CPs location height on the hydrotechnical structure, i.e., $136 \mathrm{~m}$ a.s.l., constituted the $Z$-axis. Raster maps of the distributions of averages $Z^{*}$ for horizontal displacements $\left(u x_{c}, u y_{c}, u_{c}\right)$ and vertical displacements $\left(u z_{c}\right)$, and estimation standard deviations $\sigma_{k}$ (in perspective view) were plotted in the rectangular Cartesian coordinate $(X, Y)$ system.

In this paper, selected estimation results for total resultant horizontal displacements $u_{c}$ (Figs. $5 \mathrm{a}, 5 \mathrm{~b}$ and $7 \mathrm{a}, 7 \mathrm{~b}$ ) and vertical displacements $u z_{c}$ (figs $6 \mathrm{a}, 6 \mathrm{~b}$ and $8 \mathrm{a}, 8 \mathrm{~b}$ ), measured in the years 1995 and 2007, are presented. 

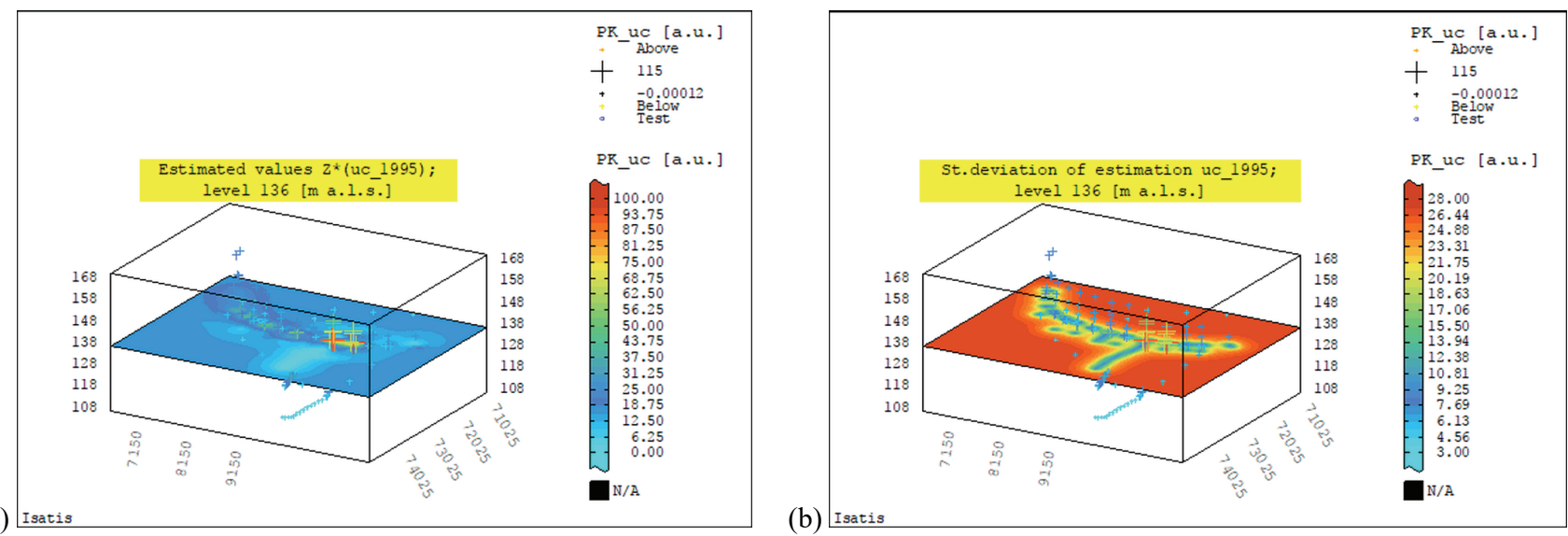

Fig. 5. The results of the estimation of horizontal displacements $u_{c}\left(u x_{c}+u y_{c}\right)$ :

(a) averages values $Z^{*}$ of displacements, (b) standard deviation of estimation $\sigma_{k}$ of displacements, 1995

(a) Isatis

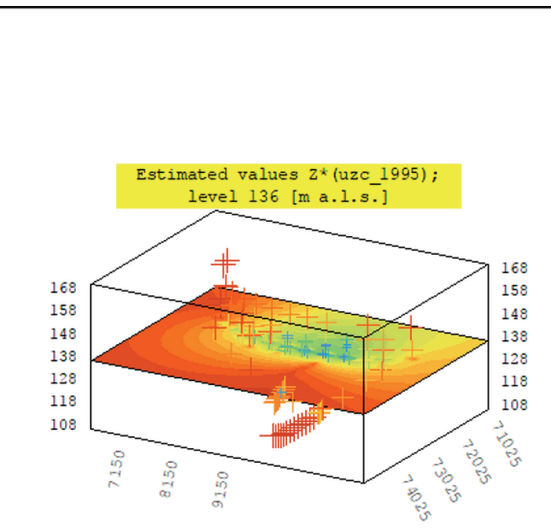

Fig. 6. The results of the estimation of vertical displacements $u z_{c}$ :

a) averages values $Z^{*}$ of displacements, b) standard deviation of estimation $\sigma_{k}$ of displacements, 1995

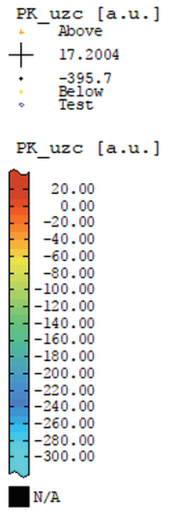

(b)

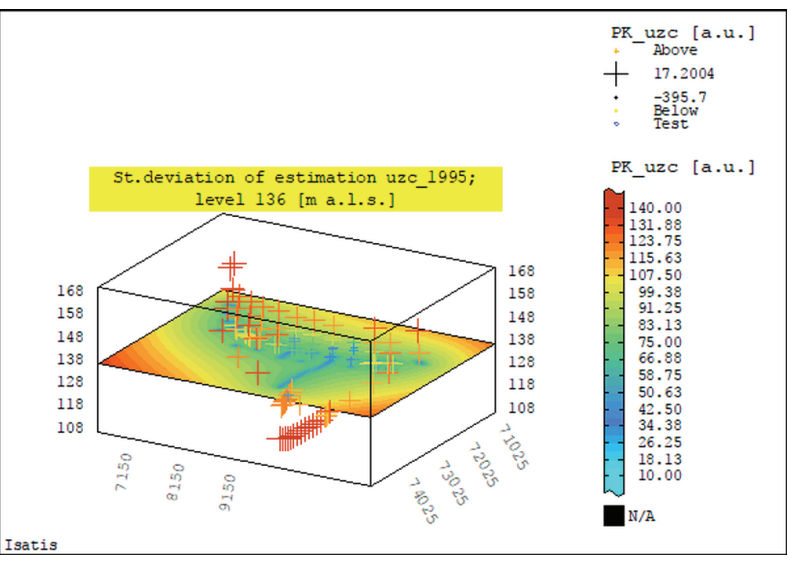

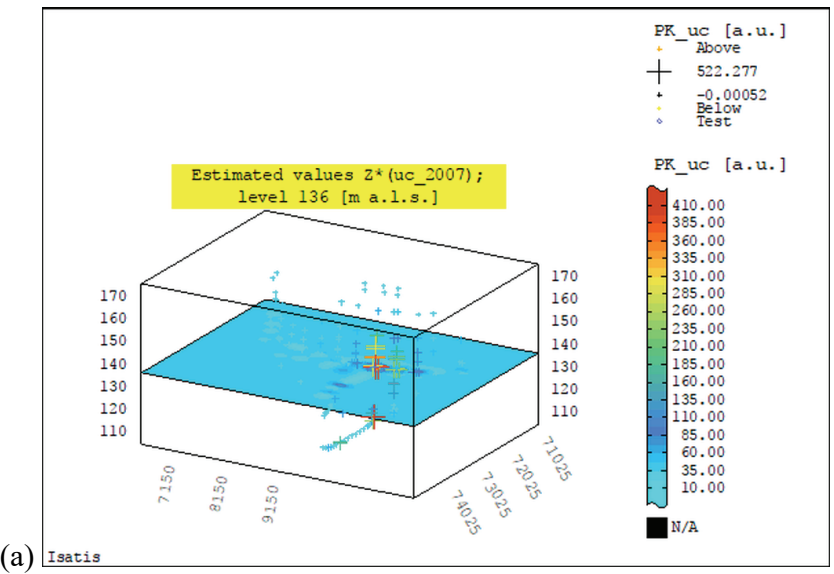

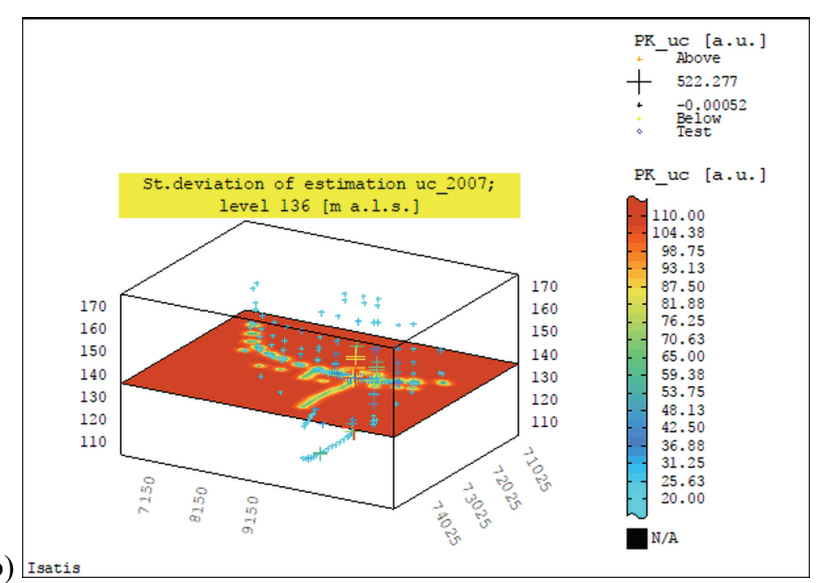

Fig. 7. The results of the estimation of horizontal displacements $u_{c}\left(u x_{c}+u y_{c}\right)$ :

(a) averages values $Z^{*}$ of displacements, (b) standard deviation of estimation $\sigma_{k}$ of displacements, 2007

Thanks to the use of ordinary block-kriging, distinct boundaries of horizonal displacements (Figs. 5a and 7a) and vertical displacements (Figs. 6a and 8a) were demarcated on the hydrotechnical structure being investigated. The zones visible on the maps of the distributions of averages $Z^{*}$, comprising the highest estimated $Z^{*}$ values, correspond to the location of CPs on the hydrotechnical structure and can be interpreted as subareas of local deformations, critical to its safety. 

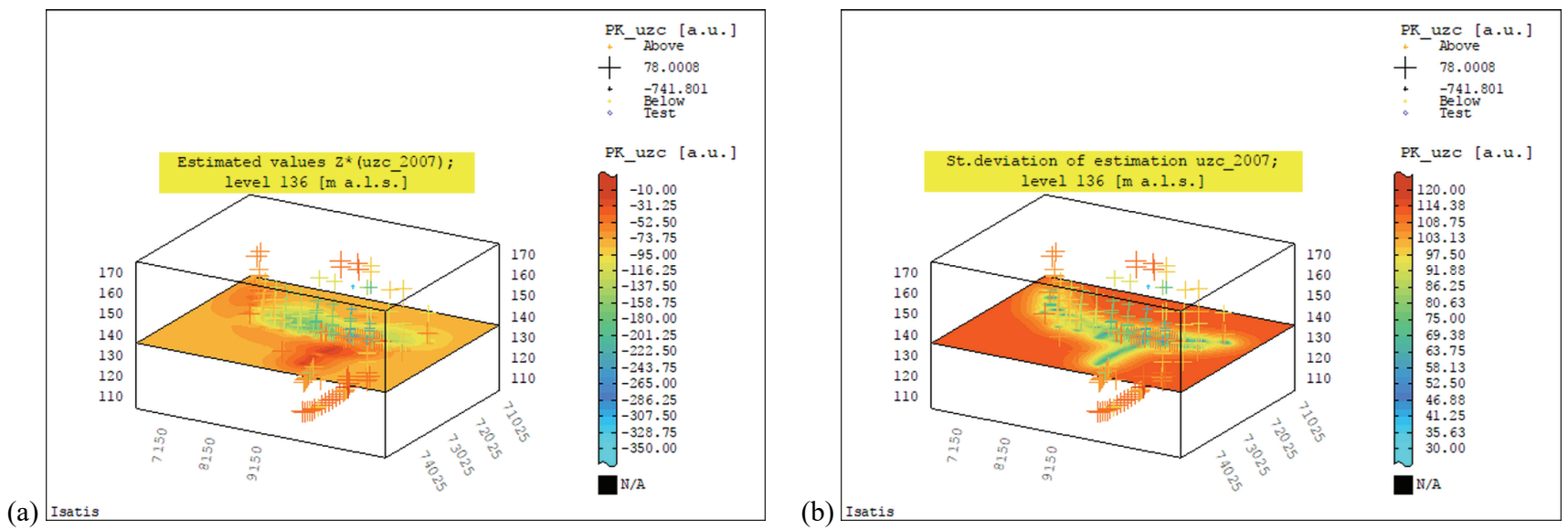

Fig. 8. The results of the estimation of vertical displacements $u z_{c}$ :

(a) averages values $Z^{*}$ of displacements, (b) standard deviation of estimation $\sigma_{k}$ of displacements, 2007

An analysis of the spatial distributions of the estimated $Z^{*}$ values shows that horizontal displacements $u_{c}$ in the considered years varied greatly. In 1995 they reached 100 a.u. while in 2007 they were much larger, exceeding 400 a.u. (Figs. 5a and 7a). Vertical displacements (subsidences) $u z_{c}$ did not vary so much, remaining on a similar level in the two years, i.e., -300 a.u. in 1995 and -350 a.u. in 2007 (Figs. 6a and 8a).

The values of estimation standard deviation $\sigma_{k}$ for the two kinds of displacements in the selected years

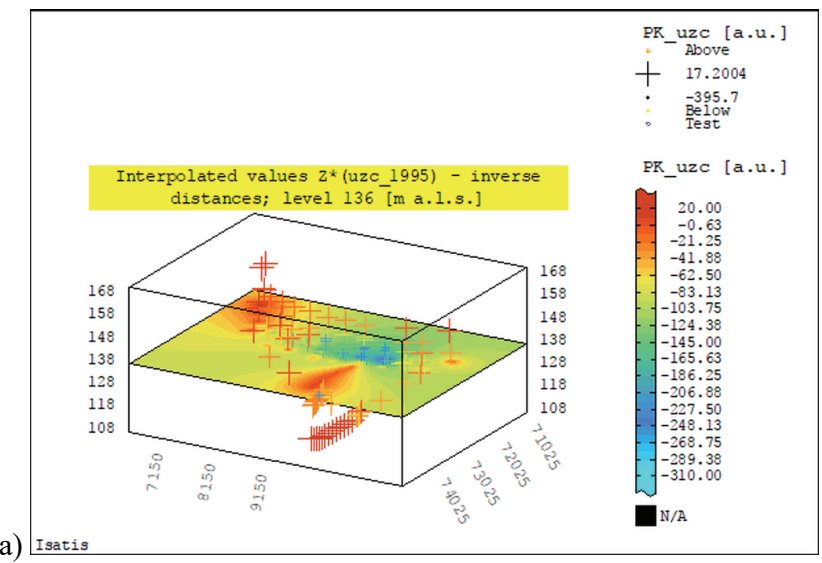

Fig. 9. The results of interpolation of vertical displacements $u z_{c}$ : (a) squared inverse distances, (b) linear model kriging, (c) spline model kriging, 1995 were, on the whole, low. Standard deviations $\sigma_{k}$ for resultant horizontal displacement $u_{c}$ ranged from several a.u. in 1995 to a few tens of a.u. in 2007. (Figs. 5b and $7 \mathrm{~b}$ ) while for the $\mathrm{CP}$ subsidences they reached up to a few tens of a.u. in the two years (Figs. $6 b$ and 8b).

\subsection{QUICK INTERPOLATION TECHNIQUES}

In the next step, quick interpolation techniques (the inverse distances squared technique, the linear

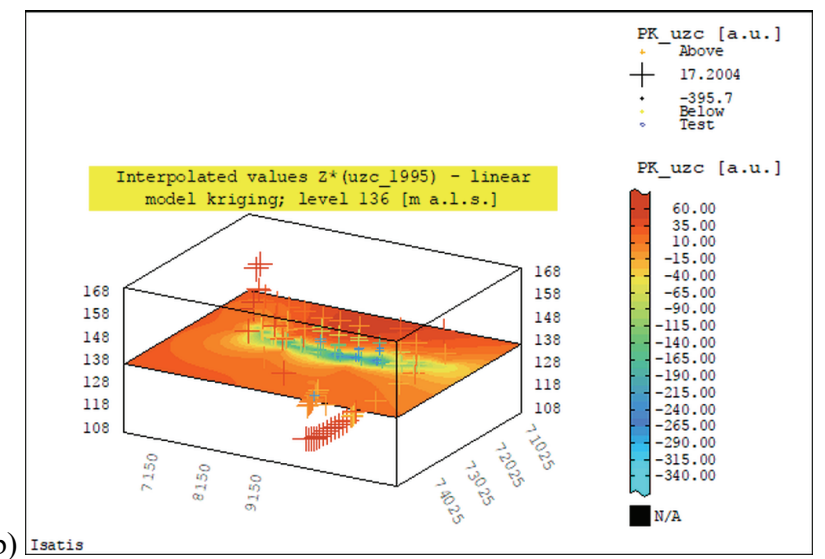

(b) Isatis

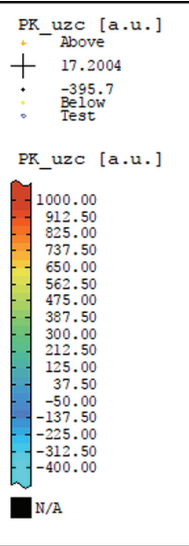




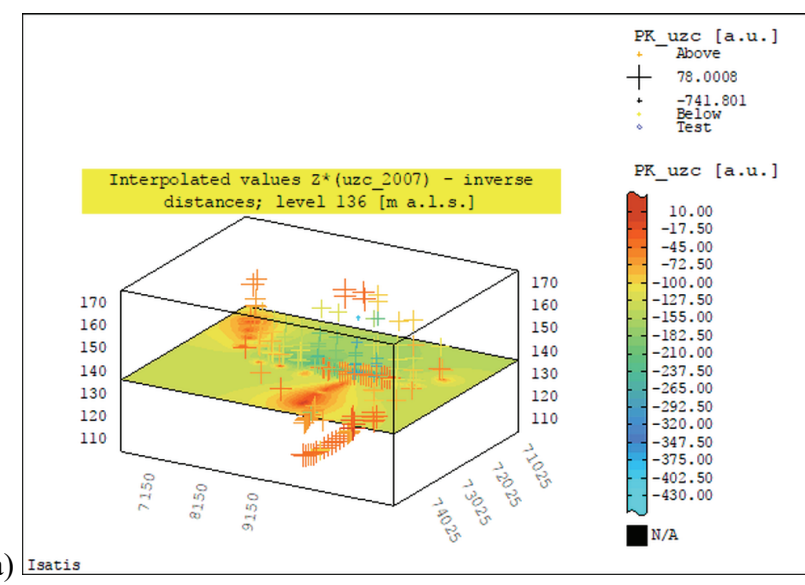

(a) Isati

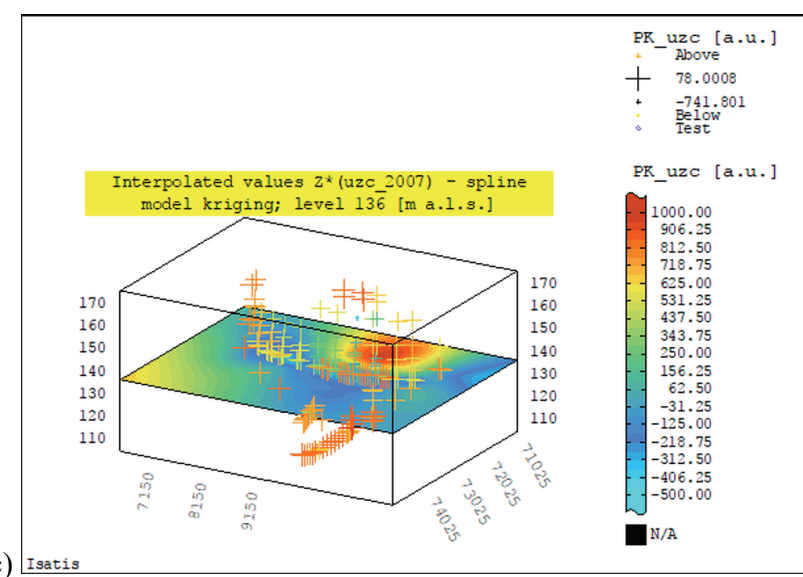

model kriging and the spline model kriging), which do not require empirical variogram models, were employed. The unique neighbourhood of searching for samples was adopted. Estimation performed by the means of these techniques is much less labourintensive and the obtained raster images of the distributions of averages $Z^{*}$ enable one to quickly get an approximate idea (background) of the variation of the studied parameter. In this case, it is possible to interactively calculate the value of $\sigma_{k}$ in a point in the analysed area. Raster maps of the interpolated $Z^{*}$ values of displacements $u z_{c}$ in 1995 and 2007 are shown in Figs. 9a, 9b, 9c and 10a, 10b, 10c, respectively.

In the raster maps showing the results of the interpolation calculations it can be noticed that the zones of displacements (Figs. 9a, 9b, 9c and 10a, 10b, 10c) lose their pocket structure and become less distinct. This effect is most pronounced in the case where the smoothed-kriging model was used. In this case, the subareas of displacements are fuzzy and the ranges of values $Z^{*}$ markedly differ from those of monitored displacement values $Z$, which indicates that they were overestimated (Figs. 9c and 10c).

Comparing the appropriate distributions for the two years considered, it can be noticed that the ranges of

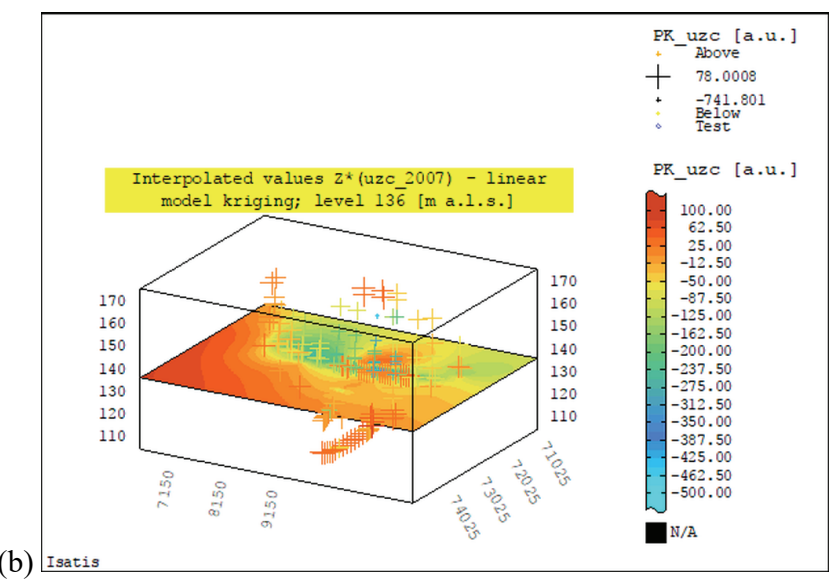

Fig. 10. The results of interpolation of vertical displacements $u z_{c}$ : (a) squared inverses distances, (b) linear model kriging,

(c) spline model kriging, 2007

the $Z^{*}$ values of vertical displacements (subsidences) $u z_{c}$, calculated using respectively the inverse distances squared technique (Figs. 9a and 10a) and ordinary block-kriging (Figs. 6a and 8a), are very similar. The other interpolation results, obtained using the linear model kriging and spline model kriging techniques, concerning the size and shape of the distinguished zones, considerably differ from the estimated $Z^{*}$ values (Figs. 9b, 9c and 10b, 10c).

The quick interpolation techniques enable getting a general idea (background) of displacements, without evaluating the accuracy of estimation of interpolated values $Z^{*}$ for the nodes in the adopted spatial grid. The interpolation standard deviation can be evaluated only in a particular point.

\section{COMPARISON OF METHODS USED}

The global statistics on the geostatistical parameters: horizontal displacements $u_{c}$ and vertical displacements $u z_{c}$ of the investigated hydrotechnical structure, obtained using ordinary block kriging and the quick interpolation methods, are presented against the background of the original data for the 
Table 8. A comparison of basic statistics of estimated averages $Z^{*}$ and interpolated values $Z^{*}$ of displacements; 2007;

ordinary kriging and techniques of quick interpolation

\begin{tabular}{|c|c|c|c|c|c|c|c|}
\hline $\begin{array}{l}\text { Analyzed total } \\
\text { displacement; } \\
2007\end{array}$ & $\begin{array}{c}\text { Geostatistical } \\
\text { parameter }\end{array}$ & \begin{tabular}{|c|} 
Size $n ;$ \\
Number of \\
grid nodes $N$
\end{tabular} & $\begin{array}{c}\text { Mean } \\
\text { value } \\
X_{\text {śr }}[\text { a.u. }]\end{array}$ & $\begin{array}{c}\text { Minimal } \\
\text { value } \\
X_{\min }[\text { a.u.] }\end{array}$ & $\begin{array}{c}\text { Maximal } \\
\text { value } \\
X_{\max }[\text { a.u. }]\end{array}$ & $\begin{array}{c}\text { Standard } \\
\text { deviation } \\
S \text { [a.u.] }\end{array}$ & $\begin{array}{c}\text { Variability } \\
\text { coefficient } \\
V[\%]\end{array}$ \\
\hline \multirow{5}{*}{ 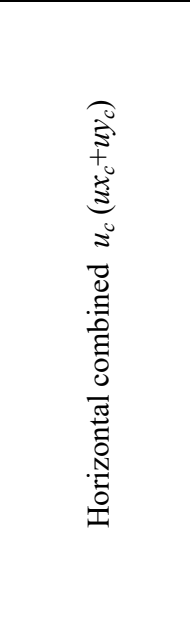 } & Original data $Z$ & 165 & 81.26 & 0.00 & 522.28 & 113.08 & 139 \\
\hline & $\begin{array}{c}\text { Estimated } \\
\text { average } Z^{*} \\
\text { (ordinary block } \\
\text { kriging) }\end{array}$ & 255840 & 37.02 & 8.80 & 343.68 & 14.33 & 39 \\
\hline & $\begin{array}{c}\text { Interpolated } \\
\text { average } Z^{*} \\
\text { (inverse squared } \\
\text { distances) }\end{array}$ & \multirow{3}{*}{255840} & 71.74 & 4.82 & 430.54 & 26.20 & 37 \\
\hline & $\begin{array}{c}\text { Interpolated } \\
\text { average } Z^{*} \\
\text { (linear model kriging) }\end{array}$ & & 19.15 & -16.12 & 479.20 & 21.61 & 113 \\
\hline & $\begin{array}{c}\text { Interpolated } \\
\text { average } Z^{*} \\
\text { (spline model kriging) }\end{array}$ & & -9.20 & -333.32 & 699.55 & 100.17 & -1089 \\
\hline \multirow{5}{*}{ 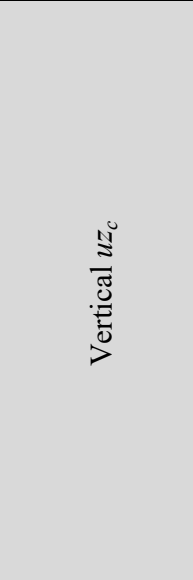 } & Original data $Z$ & 165 & -140.24 & -741.80 & 78.00 & 143.68 & -102 \\
\hline & $\begin{array}{c}\text { Estimated average } Z^{*} \\
\text { (ordinary block } \\
\text { kriging) }\end{array}$ & 255840 & -92.32 & -344.12 & -17.04 & 18.36 & -20 \\
\hline & $\begin{array}{c}\text { Interpolated } \\
\text { average } Z^{*} \\
\text { (inverse squared } \\
\text { distances) } \\
\end{array}$ & \multirow{3}{*}{255840} & -130.05 & -426.19 & 8.45 & 31.30 & -24 \\
\hline & $\begin{array}{c}\text { Interpolated } \\
\text { average } Z^{*} \\
\text { (linear model kriging) }\end{array}$ & & -37.07 & -500.72 & 85.78 & 70.65 & -191 \\
\hline & $\begin{array}{c}\text { Interpolated } \\
\text { average } Z^{*} \\
\text { (spline model kriging) }\end{array}$ & & 127.82 & -803.92 & 1120.56 & 311.14 & 243 \\
\hline
\end{tabular}

year 2007 in Table 8. Although the measured displacement values $Z$ and the mean estimated and interpolated values $Z^{*}$ cannot be directly compared, they give one an idea which of the spatial analysis methods best reflect the distribution of displacements on the structure.

The values of averages $Z^{*}$ for the two types of displacements (calculated using a 3D grid with 255840 nodes), closest to the original horizontal and vertical displacement values $Z$ (from the geodetic monitoring covering $165 \mathrm{CPs}$ ), were obtained when the ordinary block kriging technique and the inverse distances squared interpolation technique were used.

The spline model kriging yields the most divergent results of the interpolation of displacement parameter values $Z^{*}$.

A comparison of displacement averages $Z^{*}$, calculated using respectively the quick interpolation methods and the ordinary kriging technique, for the year 1990 shows that particularly highly over estimated interpolated values $Z^{*}$ are obtained when the spline model kriging was used (Figs. 11a and 11b).

An analysis of the spatial distribution of averages $Z^{*}$ of horizontal and vertical displacements $\left(u_{c}, u z_{c}\right)$ (Figs. 11a and 11b) shows that the averages differ considerably depending on the estimation technique used.

The inverse distances squared interpolation technique yielded displacement values $Z^{*}$ closest to the averages $Z^{*}$ yielded by the ordinary kriging technique, whereas the ranges of interpolated displacement values $Z^{*}$ determined using the other techniques of estimating averages were much wider. Particularly overestimated values $Z^{*}$ were yielded by the spline model kriging (Figs. 11a and 11b, Tab. 8), which was clearly reflected in their distributions visible in the raster maps (Figs. 9c and 10c). 


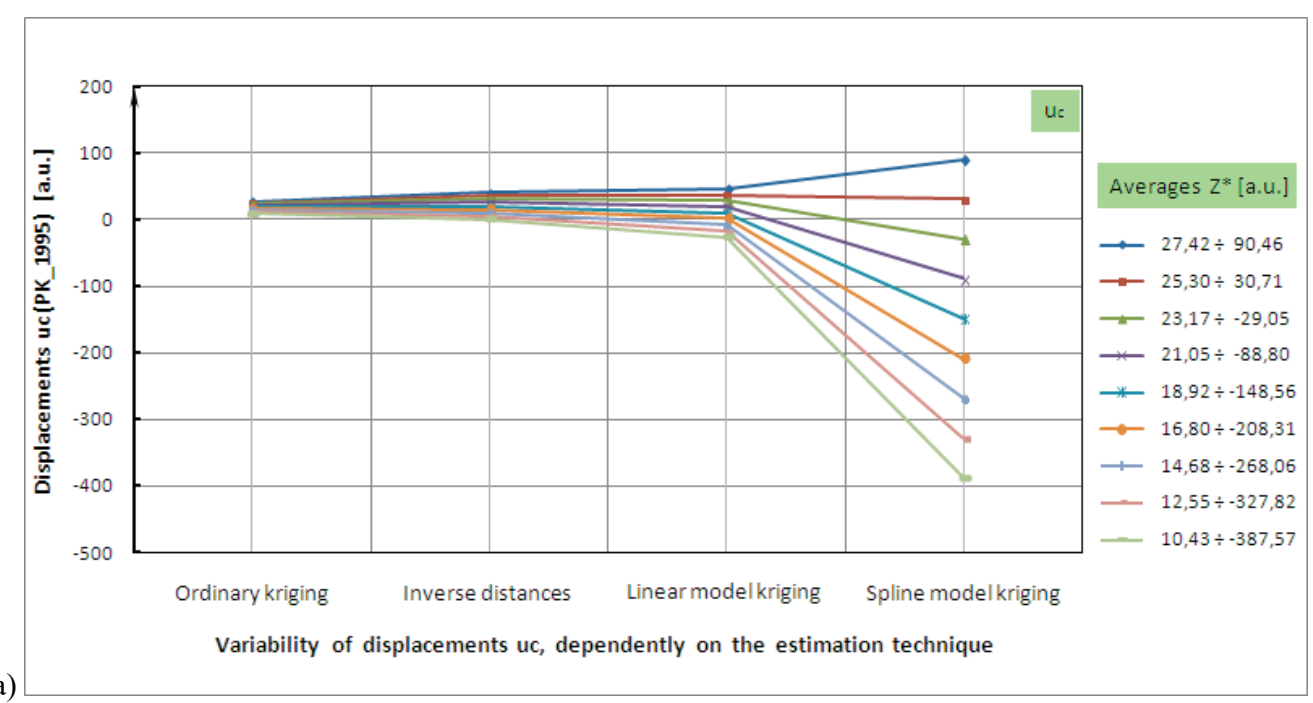

(a)

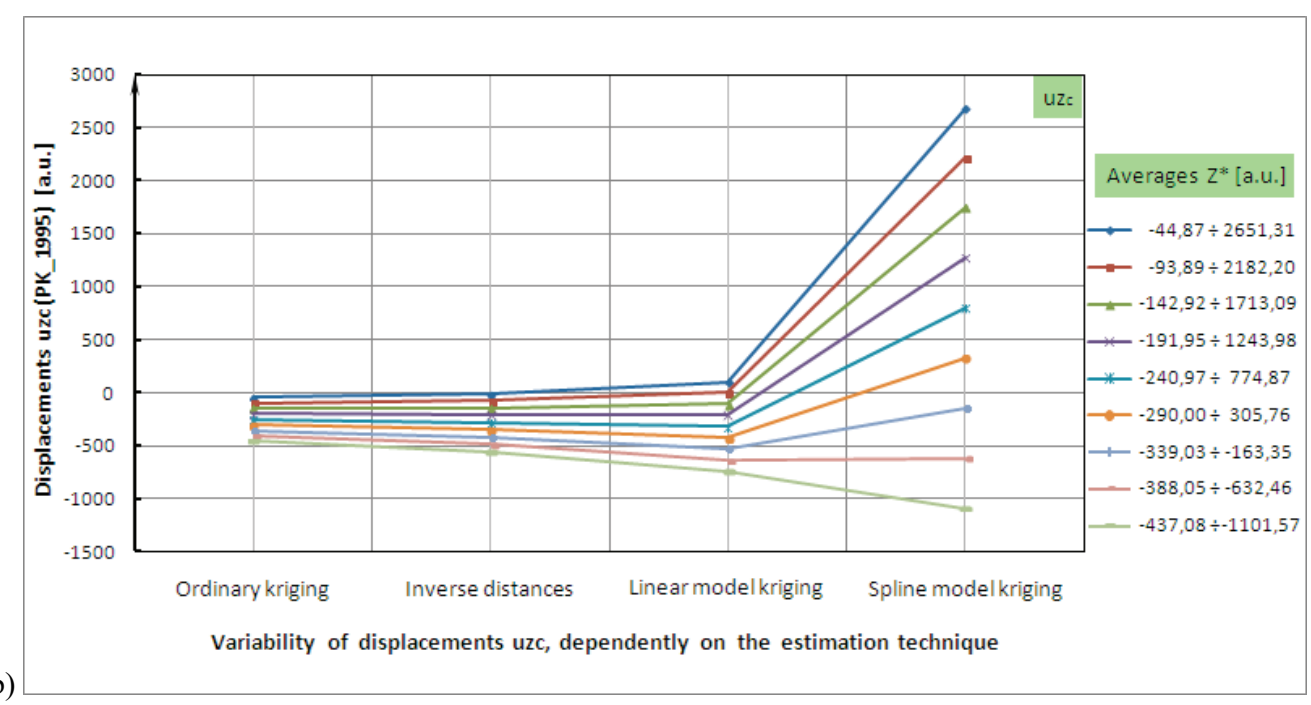

Fig. 11. The distributions of horizontal $u_{c}$ (a) and vertical $u z_{c}$ (b) displacements $Z^{*}$ of control points PK, on the dam, dependently on used techniques of the estimating of averages values $Z^{*}-1995$

\section{CONCLUSION}

The geostatistical investigations, including modelling and estimation, resulted in a rich cartographic representation (in the form of variograms, raster maps, block diagrams, etc.) of the displacements of the investigated hydrotechnical structure, on the basis of which a $3 \mathrm{D}$ geostatistical model of the variation of the displacements (presented against the area, over the time of service of the structure, with the dam height taken into account) was developed.

Based on data $Z$ coming from the geodetic monitoring of the investigated structure a spatial visualization of estimated values $Z^{*}$ of the displacements was obtained.

The use of ordinary kriging resulted in the demarcation of the boundaries of zones of horizontal dis- placements and vertical displacements (subsidences and uplifts) on the structure.

The advantage of ordinary kriging over the quick interpolation techniques can be explained by the fact that it yielded the averages $Z^{*}$ of the displacements together with the estimation uncertainty, i.e., values of estimation standard deviation $\sigma_{k}$ calculated in the nodes of the spatial elementary grid covering the investigated structure. It should be noted that in the case of ordinary kriging the parameters in indicated point locations can be determined interactively, especially when the geometry of the structure is to change or when the grid of check points needs to be extended. Such possibilities also exist when some of the quick interpolation techniques, e.g., the linear model kriging or the spline model kriging, are used, but this can be applied to calculations in selected 
point locations only, not in the nodes of the spatial elementary grid.

The investigations have shown that the geostatistical techniques can be an effective tool in geodesy. They can be used to carry out spatial analyses of the displacements of any small- and large-area structures (weirs, dams, urbanized areas in the neighbourhood of deep excavations, macroregion-size areas subjected to anthropogenic influences resulting from, e.g., mining, etc.). Such analyses are vital for the assessment of the safety of important hydrotechnical structures.

\section{REFERENCES}

[1] Clark I., Practical geostatistics, Appl. Sc. Publishers, London, 1979, 1-129.

[2] DAVID M., Handbook of Applied Advanced Geostatistical Ore Reserve Estimation Developments in Geomathematics, Elsevier Science Publishers, B.V., Amsterdam, the Netherlands 1988, $1-216$.

[3] Journel A.G., Huijbregts C.J., Mining Geostatistics, Academic Press, London, New York, San Francisco, 1978, 1-600.

[4] KiciaK P., Podstawy modelowania krzywych i powierzchni, Wydawnictwa Naukowo-Techniczne, Warszawa 2000.

[5] Matheron G., Traite de Geostatistique Appliquee: Memoires du Bureau de Recherches Geologique et Minieres, vd. 14, Editions Technip., Paris 1962, 1-333.

[6] Mucha J., Metody geostatystyczne $w$ dokumentowaniu złóz, AGH, Kraków 1994, 1-155.

[7] NAMYSŁOWSKA-WILCZYŃSKA B., Zmienność złóż rud miedzi na monoklinie przedsudeckiej $w$ świetle badań geostatystycznych, Prace Naukowe Instytutu Geotechniki i Hydrotechniki Politechniki Wrocławskiej nr 64. Seria: Monografie nr 21, Wrocław 1993, 1-207.

[8] NAMYSŁOWSKA-WiLCZYŃSKA B., Geostatystyka. Teoria i zastosowania, Oficyna Wydawnicza Politechniki Wrocławskiej, Wrocław 2006, 365.

[9] NAMYSŁOWSKA-WilcZYŃSKA B. (ed.)., Modelowanie Procesów Hydrologicznych, Praca zbiorowa Namysłowska-Wilczyńska B., Modelowanie i prognozowanie (3D) wysokości opadu atmosferycznego i zawartości siarczanów $\mathrm{SO}_{4} w$ opadzie na obszarze dorzecza środkowej Odry z zastosowaniem geostatystyki, Oficyna Wydawnicza Politechniki Wrocławskiej, Wrocław 2008, 526, 35-74.

[10] NAMYSŁOWSKA-WILCZYŃSKA B., PYRA J., Integration of Data from Soil and Underground Waters Monitoring Grids by Kriging with External Drift, Processing of Terra Nostra, 8th Annual Conference of the International Association for Mathematical Geology (IAMG 2002), Berlin, 15-20 September 2002, 475-480.

[11] NamysŁowska-WilczyŃSKa B., PYRA J., Rola precyzji ocen parametrów środowiskowych $w$ edukacji ekologicznej, Polskie Towarzystwo Inżynierii Ekologicznej, Edukacja Ekologiczna. Podstawy Działań Naprawczych w Środowisku. Wydawnictwo Naukowe Lublin, Nałęczów 2004, 199-213.

[12] NAMYSŁOWSKA-WilcZYŃSKA B., RUSAK K., Geostatistics description of heavy metal content variation in soil of Olkusz region against a background of geological structure by GIS metod, Mathematische Geologie, Vol. 7, Mathematical Meth- ods Applied to Geology and Mining, Mining. Mathematische Methoden in Geologie und Bergbau, CPress Verlag. Band 7, Dresden, December 2003, 51-63.

[13] NAMYsŁowsKa-WilczyŃSKa B., RUSAK K., Zastosowanie geostatystyki i GIS do analizy wpływu czynników naturalnych $i$ antropogenicznych na koncentrację metali cięzkich $w$ glebach rejonu olkuskiego, Polskie Towarzystwo Informacji Przestrzennej, Warszawa. III Ogólnopolskie Sympozjum Geoinformacyjne "Geoinformacja w Badaniach Przestrzennych", Warszawa, 7-9.11.2005, Roczniki Geomatyki, 2005, z. 2, t. III, 115-124.

[14] NAMYSŁOWSKA-WilCZyŃSKA B., WynaleK J., The analysis of vertical displacements for a hydrotechnical facility using geostatistics. Part 2. Determining the probability of displacement occurrence and its prediction, Studia Geotechnica et Mechanica, 2011, Vol. 33, No. 2, 67-75.

[15] NAMYSLOWSKA-WILCZYŃSKA B., WYNALEK J., The analysis of vertical displacements for a geotechnical facility using geostatistics. Part 1. Structural analysis and estimation of displacements, Studia Geotechnica et Mechanica, 2011, Vol. 33, No. 1, 33-54.

[16] NAMYSŁoWSKA-WILCZYŃSKA B., SKORUPSKA B., WIENIEWSKI A., Analiza geostatystyczna zmienności parametrów technologicznych popiołożużli zdeponowanych na składowisku odpadów przemystowych, Ochrona Środowiska, 2012, Vol. 34, nr 2, 43-48.

[17] NAMYSŁOWSKA-WILCZYŃSKA B., Geostatistical methods used to estimate Sieroszowice cop per ore deposit parameter, Zeitschrift für Geologische Wissenschaften, Journal for the Geological Sciences, Berlin, 2012, 40(6), 329-361.

[18] NAMYSŁOWSKA-WILCZYŃSKA B., Geostatistical hydrogeochemical $3 D$ model for Kłodzko underground water intake area. Part I. Estimation of basic statistics on quality parameters of underground waters, Studia Geotechnica et Mechanica, 2013, Vol. 35, No. $1,157-181$.

[19] NAMYSŁOWSKA-WilczyŃSKA B., Szacowanie parametrów jakościowych wody podziemnej z wykorzystaniem krigingu zwyczajnego dla obszaru ujęć w rejonie Kłodzka, Monografia XX KK KOWBAN 2013 Krajowej Konferencji "Komputerowe Wspomaganie Badań Naukowych", Polanica Zdrój, 23-25.10.2013.

[20] NAMYsŁowskA-WilczyŃsKa B., WynaleK J., Analiza przestrzenna pola przemieszczeń na podstawie monitoringu geodezyjnego, Infobazy 2014, Inspiracja - Integracja - Implementacja: VII Krajowa Konferencja Naukowa, GdańskSopot, 8-10 września 2014, Gdańsk: Politechnika Gdańska, [2014], Dokument elektroniczny (pendrive), 1-12.

[21] NAMYSŁOWSKA-WiLCZYŃSKA B., WYNALEK J., Badania geostatystyczne przemieszczeń na podstawie danych z monitoringu geodezyjnego obiektu hydrotechnicznego, Zeszyt Streszczeń Referat: XI Konferencja Naukowo-Techniczna KNTPH "Problemy Hydrotechniki”, Świeradów-Zdrój, 10-12 maja 2017, 52-53.

[22] Osada E., Analiza, wyrównanie i modelowanie geo-danych, Wyd. Akademii Rolniczej we Wrocławiu, 1998.

[23] RejMAn J., WoźNIAK J., Geograficzne Systemy Informacyjne w badaniach współczesnych ruchów skorupy ziemskiej, Materiały III Krajowej Konferencji - Komputerowe Wspomaganie Badań Naukowych III KK KOWBAN '96, Wrocławskie Towarzystwo Naukowe, Wrocław, 17-19 października 1996, 193-198.

[24] WaCKernagel H., Multivariate Geostatistics, SpringerVerlag, Berlin, Heidelberg, New York, 1995, 256. 